ISSN : 2550-0198

\title{
PENTINGNYA AKURASI DAN PRESISI ALAT UKUR DALAM RUMAH TANGGA
}

\author{
Neneng Fitrya*, Delovita Ginting, Sri Fitria Retnawaty, Noni Febriani, Yulia \\ Fitri, Shabri Putra Wirman \\ Fakultas MIPA dan Kesehatan, Universitas Muhammadiyah Riau \\ Universitas Muhammadiyah Riau \\ *Email: nenengfitrya@umri.ac.id
}

\begin{abstract}
Abstrak
Dalam kehidupan sehari-hari dirumah tangga tidak bisa terlepas juga dari masalah pengukuran, misalkan pada saat pembelian beras, gula, minyak goreng dan keperluan rumah tangga lainnya akan dihadapkan dengan penggunaaan alat ukur. Berkaitan dengan penggunaan alat ukur ini, sering ditemukan kasus ketidaksamaan hasil pengukuran. Beberapa kasus ketidaksamaan pengukuran, diantaranya ketidaksamaan dalam ukuran timbangan, literan dan bahkan meteran. Tujuan dari pengabdian ini adalah memberikan informasi kepada masyarakat khususnya ibu-ibu posyandu akan pentingnya masalah akurasi dan presisi dari alat ukur, sehingga dapat mengatasi masalah katidaktepatan dari pengukuran. Kegiatan pengabdian kepada masyarakat (PPM) ini dilaksanakan di RT 001, RW 012 , Kelurahan Lembah Sari, Kecamatan Rumbai Pesisir, Kota Pekanbaru. Peserta yang hadir dalam kegiatan ini adalah ibu-ibu posyandu dari RT tersebut. Peserta memperoleh tambahan informasi, pengetahuan, pengalaman tentang pentingnya akurasi dan presisi alat ukur dalam rumah tangga yang telah diberikan, peserta ingin menerapkan hasil yang diperoleh di kehidupan sehari-hari.
\end{abstract}

Kata kunci: Alat Ukur, Akurasi dan Presisi

\section{PENDAHULUAN}

Pengukuran berperan penting hampir pada semua aktivitas manusia. Kegiatan pengukuran mempunyai dampak yang luas terhadap ilmu pengetahuan, kehidupan pribadi manusia dan masyarakat dalam meningkatkan efisiensi. Alat ukur yang digunakan tergantung pada besaran ukur yang akan diukur. Alat ukur telah lama dipergunakan manusia dalam kehidupan sehari-hari, baik untuk perdagangan, pembangunan, bahkan aktifitas rumah tangga. Kesalahan dalam pengukuran sering terjadi, seperti ketidaktepatan hasil pengukuran. Hal ini disebabkan oleh beberapa faktor diantaranya tidak beroperasinya alat ukur dengan baik atau alat ukur memberikan data hasil pengukuran yang salah.

Permasalahan ketidaktepatan dalam pengukuran dari suatu alat ukur ini dapat diatasi dengan melakukan kalibrasi ulang pada alat tersebut. Kalibrasi alat ukur ini bertujuan untuk memverifikasi bahwa suatu alat ukur sesuai dengan rancangannya. Kalibrasi merupakan kegiatan yang membandingkan suatu standar yang tertelusur dengan standar nasional atau internasional dan bahan-bahan acuan tersersertifikasi. [1][2]. Manfaat kalibrasi adalah Menjaga kondisi 
ISSN : 2550-0198

instrumen ukur dan bahan ukur agar tetap sesuai dengan spesefikasinya [1][2], sehingga tetap akurat dan presisi. Akurasi dalam pengukuran merupakan tingkat kedekatan pengukuran kuantitas terhadap nilai yang sebenarnya [3], sedangkan Kepresisian dari suatu sistem pengukuran diartikan sejauh mana pengulangan pengukuran dalam kondisi yang tidak berubah mendapatkan hasil yang sama [4].

Dalam kehidupan sehari-hari dirumah tangga tidak bisa terlepas juga dari masalah pengukuran, misalkan pada saat pembelian beras, gula, minyak goreng dan keperluan rumah tangga lainnya akan dihadapkan dengan penggunaaan alat ukur. Berkaitan dengan penggunaan alat ukur ini, sering ditemukan kasus ketidaksamaan hasil pengukuran. Beberapa kasus ketidaksamaan pengukuran, diantaranya ketidaksamaan dalam ukuran timbangan, literan dan bahkan meteran. Tahun 2015 terjadi kasus yang dialami oleh seorang ibu rumah tangga, dimana pembayaran PDAM melonjak tinggi dibandingkan biasanya. Masalah ini ternyata diakibatkan oleh meteran PDAM yang sudah tidak akurasi dan presisi, sehingga volume yang terukur tidak sesuai dengan keadaan sebenarnya. Hal tersebut membuat kerugian bagi pihak pengguna.

Sehubungan dengan hal tersebut di masyarakat, maka masyarakat dirasa perlu untuk mendapat pengetahuan dan pemahaman tentang ketepatan (akurasi dan presisi) alat ukur tersebut dan tindakan apa yang harus dilakukan jika alat ukur tersebut sudah tidak tepat lagi.
Tujuan dari pengabdian ini adalah memberikan informasi kepada masyarakat khususnya ibu-ibu posyandu akan pentingnya masalah akurasi dan presisi dari alat ukur, sehingga dapat mengatasi masalah katidaktepatan dari pengukuran. Hal ini diharapkan bisa mengurangi resiko dan tingkat kerugian yang disebabkan oleh kesalahan pengukuran.

\section{METODE PENGABDIAN}

Kegiatan pengabdian kepada masyarakat (PPM) ini dilaksanakan di RT 001, RW 012, Kelurahan Lembah Sari, Kecamatan Rumbai Pesisir, Kota Pekanbaru. Peserta yang hadir dalam kegiatan ini adalah ibu-ibu posyandu dari RT tersebut.

Tabel. 1. Kegiatan materi dan waktu yang disampaikan selama pelatihan

\begin{tabular}{|c|c|c|}
\hline No & Pukul & $\begin{array}{c}\text { Kegiatan dan Jenis } \\
\text { Materi yang } \\
\text { diberikan }\end{array}$ \\
\hline 1 & $08.00-08.15$ & $\begin{array}{c}\text { Sarapan dan } \\
\text { peserta datang }\end{array}$ \\
\hline 2 & $08.15-08.20$ & $\begin{array}{c}\text { Pembukaan oleh } \\
\text { protokol }\end{array}$ \\
\hline 3 & $08.25-08.30$ & $\begin{array}{c}\text { Pembukaan oleh } \\
\text { ketua pelaksana } \\
\text { Sosialisasi yang } \\
\text { terdiri dari } \\
\text { Ceramah dan } \\
\text { diskusi }\end{array}$ \\
\hline 5 & $08.30-09.30$ & $\begin{array}{c}\text { Diskusi dan tanya } \\
\text { jawab }\end{array}$ \\
\hline
\end{tabular}

Pada setiap tahap kegiatan dilakukan evaluasi dengan cara berupa tanya jawab (diskusi) dan pengamatan oleh peserta (ibu-ibu posyandu). Pelaksanaan kegiatan ini dengan menggunakan metode: ceramah, dialog dan diskusi. Kegiatan diisi dengan materi-materi tentang 
alat ukur, kalibrasi alat ukur dan sosialisasi pentingnya masalah akurasi dan presisi dari alat ukur agar bisa meminalisir kerugian yang disebabkan oleh kesalahan atau tidak akurat dan presisinya alat ukur yang digunakan.

Tim pelaksana mengusahakan adanya masukan-masukan, tanya jawab dan juga diskusi secara nonformal dengan peserta serta praktek langsung untuk mengatasi masalah yang mungkin muncul dan untuk menunjang keberhasilan tujuan dan manfaat kegiatan.

\section{HASIL DAN PEMBAHASAN}

Peserta pelatihan yang hadir terdiri dari ibu-ibu peserta posyandu, pengurus posyandu, bidan dan perangkat RT. Dari hasil diskusi dengan peserta, hampir semua dari peserta yang hadir sering menggunakan alat ukur, baik untuk keperluan rumah tangga, perdagangan maupun untuk pelayanan kesehatan. Dari hasil diskusi juga, ternyata sebagian besar dari peserta banyak yang belom tahu masalah akurasi, presisi dan kalibrasi dari alat ukur.

Kebiasaan yang terjadi selama ini, alat ukur tidak pernah dikalibrasi, dari pembelian alat ukur tersebut akan terus dipakai sampai bertahun-tahun sampai alat tersebut rusak. Peserta tidak mengetahui kerugian yang diakibatkan ketika alat ukur sudah tidak akurat dan presisi.

Kegiatan diisi dengan materimateri tentang alat ukur seperti timbangan, regulator gas, meteran air PDAM dan alat ukur volume, masalah akurasi dan presisi alat ukur, kalibrasi alat ukur dan sosialisasi pentingnya masalah akurasi dan presisi serta tempat kalibrasi alat ukur jika sudah diperlukan pengkalibrasian. Tujuan nya agar bisa meminalisir kerugian yang disebabkan oleh kesalahan tidak akurat dan presisinya alat ukur yang digunakan.

Pada kegiatan ini, juga dibahas kapan dan seperti apa kondisi alat ukur yang sudah tidak akurasi dan presisi sehingga diperlukan pengkalibrasian ulang. Selain itu juga ditampilkan beberapa contoh kerugian yang disebabkan alat alat ukur yang sudah tidak akurat.

\section{SIMPULAN}

Peserta memperoleh tambahan informasi, pengetahuan, pengalaman tentang pentingnya akurasi dan presisi alat ukur dalam rumah tangga yang telah diberikan, peserta ingin menerapkan hasil yang diperoleh di kehidupan sehari-hari.

Beberapa peserta mengharapkan kegiatan berlanjut dengan pengkalibrasian langsung alat ukur yang sering digunakan seperti timbangan.

\section{UCAPAN TERIMAKASIH}

Terimakasih kepada Universitas Muhammadiyah Riau sebagai pihak yang memberikan dana untuk pelaksanaan kegiatan ini. Terimakasih kepada Lembaga Penelitian dan Pengabdian kepada Masyarakat (LP2M) sebagai lembaga media dan administrasi pengurusan kegiatan ini. Terimakasih kepada ketua RT 001 dan pengurus posyandu RT 001, RW 012, Kelurahan Lembah 
Sari, Kecamatan Rumbai Pesisir, Kota Pekanbaru yang telah memfasilitasi tempat kegiatan ini. Terimakasih kepada semua dosen Fisika UMRI dan mahasiswa yang terlibat dalam pelaksana kegiatan ini.

\section{DAFTAR PUSTAKA}

[1] Morris, Alan S., "Measurement and Instrumentation Principles", Butterworth Heinemann, ISBN 0-75065081-8, 2001.

[2] Pyzdek, T, "Quality Engineering Handbook", ISBN 0-8247-4614-7, 2003.

[3] JCGM 200: International vocabulary of metrologyBasic and general concepts and associated terms (VIM), 2008.

[4] John Robert Taylor (1999). An Introduction to Error Analysis: The Study of Uncertainties in Physical Measurements, University Science Books. pp. 128-129. ISBN 0-935702-75$\mathrm{X}$. 